\title{
PARTICIPATION OF THE POLISH ARMY IN THE UNITED NATIONS MISSION IN THE REGION OF THE GOLAN HEIGHTS - UNITED NATIONS DISENGAGEMENT OBSERVER FORCE
}

\begin{abstract}
The article presents the issue of participation of the Polish Army in foreign UNDOF missions (United Nations Disengagement Observer Force), the history of its participation and changes in the nature of the mission. The first part of the article presents the legal basis for peacekeeping missions under the auspices of the United Nations, the concept of using the UN peacekeeping forces as one of the measures to the peaceful resolution of conflicts. It discusses the types of operations carried out by the United Nations, namely: first generation of peacekeeping operations, second generation of peacekeeping operations and peace enforcement operations. The operations of the first and second generation function in accordance with the agreement of the parties, impartiality, failing to use force, except in self-defense. In peace enforcement operations the mandate allows for derogations from the rules. The paper discusses the major Israeli-Arab conflicts, which have become a contribution to the UN intervention in the Middle East. Then, it describes the first peacekeeping operation in the Sinai Peninsula, which was participated in by the Polish Army as a unified national contingent (1973-1979), entrusted with certain tasks in the framework of the United Nations forces. The mission was named UNEF II (United Nations Emergency Force II). This contingent was responsible for securing logistics: medical supply, supply of drinking water and food, and mine clearing. The second peacekeeping operation, participated in by the Poles, was the mission on the Golan Heights - UNDOF. This operation, like the mission in Egypt (UNEF II), was a result of the Arab-Israeli war in 1973. The presence of peacekeeping forces became possible after the agreements made in May 1974 in Geneva, between Syria and Israel. The task of the peacekeeping forces was to supervise a truce between the conflicting parties. This mission was the longest-lasting mission of the Polish Army (1974-2009).
\end{abstract}

Keywords: UN peacekeeping missions, UNDOF, Polish Army in peacekeeping missions.

\section{LEGAL BASIS OF UN PEACEKEEPING MISSIONS}

Peacekeeping missions are associated with the activities of the United Nations (UN) ${ }^{2}$, which until the end of the eighties of the last century was de facto the only international

\footnotetext{
${ }^{1}$ Tadeusz Olejarz PhD, Department of Humanities, Faculty of Management, Rzeszow University of Technology, Al. Powstańców Warszawy 8, 35-959 Rzeszów, tel. 177432337,e-mail: olejarz@prz.edu.pl

${ }^{2}$ W. Malendowski, Rola ONZ w utrzymaniu pokoju i bezpieczeństwa międzynarodowego, [w:] Stosunki międzynarodowe, red. W. Malendowski, Cz. Mojsiewicz, Atla 2, Wrocław 2004, s. 403.
} 
organization conducting such actions in accordance with its primary task of maintaining international peace and security, written in the Charter of the United Nations ${ }^{3}$.

The UN was based on the war alliance between the US, Britain and the USSR, which gave the opportunity to take action in order to establish peace after the Second World War. The basis of the alliance was the collaboration of big powers in favor of world peace $^{4}$. At that time all sorts of variants of the post-war security system ${ }^{5}$ were analyzed from the close relationship of nations, similar to the federation under a single joint authority, to some cautious solutions, e.g. establishment of a political organization, dealing with issues of international security ${ }^{6}$.

The UN was formally established by the governments of 51 countries on 24 October 1945. Its basic aims included ${ }^{7}$ :

1. maintenance of international peace and security with the use of effective collective measures for the prevention of threats to peace and eliminating them (disputes or situations which might lead to a distortion of peace were to be settled peacefully), in accordance with the principles of justice and international law,

2. development of friendly relations among nations based on respect for the principles of equal rights and self-determination of peoples, using appropriate measures to strengthen universal peace,

3. solving, through international cooperation, problems of an economic, social, cultural and humanitarian nature, as well as promoting and encouraging respect for human rights and fundamental freedoms, regardless of race, gender and religion,

4. establishment of the center for harmonization of the United Nations actions to achieve these common goals.

The main body of the UN is the General Assembly, which meets once every year. Each Member State has one vote in it. The second most important body the United Nations as an institution is the Security Council. It is composed of five permanent members: China, France, the USA, Great Britain and Russia, as well as ten nonpermanent members elected by the General Assembly every two years. The task of this body are actions to maintain peace in the world ${ }^{8}$.

The Security Council, in accordance with the Charter of the United Nations, takes actions to keep the peace. Of particular importance are the resolutions of the Security Council, concerning the maintenance of international peace and security, especially decisions to apply sanctions that do not require the use of force (Art. 41 of the Charter) and the decisions of military sanctions (Art. 42 of the Charter) ${ }^{9}$. As the only resolutions passed by the UN bodies, they are legally binding on the states - by virtue of Art. 25 of the

${ }^{3}$ T. Łoś-Nowak, Organizacje w stosunkach międzynarodowych, Wrocław 1997, s. 82-83, Międzynarodowe operacje pokojowe w doktrynie obronnej RP, red. F. Gągor, Adam Marszalek, Warszawa 1998, s. 15

${ }^{4}$ Bezpieczeństwo Świat-Europa Polska, red. J. Kaczmarek, Alta, Wrocław, 1998, s. 44.

${ }^{5}$ For more, see. J. T. Limanowski, Operacje pokojowe Organizacji Narodów Zjednoczonych, Warszawa 2011.

${ }^{6}$ M. Baran, Zabezpieczenie logistyczne Polskiego Kontyngentu Wojskowego w misji pokojowej (na przykładzie KFOR), praca studyjna - maszynopis [mps], AON, Warszawa 2003, s. 11.

${ }^{7}$ L. Zapałowski, Operacje pokojowe ONZ, KAW, Kraków 1989, s. 19-20.

${ }^{8}$ http://www.un.org/en/sc/members/

${ }^{9}$ L. Łukaszuk, A. Skowroński, Międzynarodowe prawo pokoju i bezpieczeństwa, AON, Warszawa 1999, s. 224. 
Charter ${ }^{10}$. Their legality cannot be questioned, they are not subject to judicial review by the International Court of Justice, as well ${ }^{11}$.

Council's decisions in formal matters are passed by the majority of votes, but in substantive matters by a majority of nine votes, including the unanimity of the permanent members of the Council. To perform the tasks facing the Council, the organization can use certain collective measures for the prevention of threats to peace and the suppression of all acts of aggression ${ }^{12}$. These measures include diplomatic actions provided in Chapter VI of the Charter, consisting mainly in the recommendations of a peaceful resolution of the conflict by the parties concerned, in accordance with the relevant Security Council resolution. In addition, the Security Council may apply coercive measures as provided in Chapter VII of the Charter, which include economic and political sanctions, involving the partial or complete breaking of diplomatic and economic relations. When these measures do not produce the intended effect, the Council may use the armed forces of the Member States to carry out a demonstration of power, blockade or other military operations considered necessary in order to maintain or re-establish peace and security.

In 1956, the concept of using the UN peacekeeping forces as one of the measures to the peaceful resolution of conflicts was developed ${ }^{13}$. The main task of the peacekeeping forces was to separate the conflicting parties, supervise the withdrawal of forces and respect the adopted agreements ${ }^{14}$. The standards developed at that time are now considered as fundamental principles of peacekeeping operations ${ }^{15}$.

Today we can talk about three types of operations conducted by the United Nations ${ }^{16}$. These include first generation of peacekeeping operations, second generation of peacekeeping operations and peace enforcement operations ${ }^{17}$.

As rightly pointed out by Przemysław Hudyma in the doctoral dissertation ${ }^{18}$, peacekeeping operations carried out in the years 1956-1988 are classified as the first

\footnotetext{
${ }^{10}$ Art. 25 of the Charter provides that: Members of the United Nations agree to accept and carry out the decisions of the Security Council under the present Charter.

${ }^{11}$ W. Czapliński, A. Wyrozumska, Prawo międzynarodowe publiczne. Zagadnienia systemowe, wyd. II, C.H. Beck, Warszawa 2004, s. 373.

${ }^{12}$ L. Zapałowski, op. cit., s. 19-20.

${ }^{13}$ J. Ciechański, I. Wyciechowska, Teoria pokoju a Organizacja Narodów Zjednoczonych, Sprawy Międzynarodowe, Akademia Dyplomatyczna, nr 6, Warszawa 1990, s. 51.

14 Ibidem, s. 14.

${ }^{15} \mathrm{UN}$ peacekeeping forces are deployed in the separation zone with the consent of the conflicting parties. Military contingents should be called up from non-aligned countries on a voluntary basis; peacekeeping forces cannot get involved on either side of the conflict and are obliged to strictly comply with the principle of impartiality; UN Secretary-General has control over the operation of these forces. Ibidem, s. 15, P. Hudyma, Udziat wojsk polskich $w$ misjach zagranicznych o charakterze pokojowym i stabilizacyjnym, w latach 1953-2008, praca doktorska - mps, Poznań 2011, s. 13-15.

${ }^{16}$ See S. Kinloch-Pichat, International Peacekeeping, Disarmament and International Force: A Circular Proposition, (Peacekeeping: evolution or extinction?). Disarmament Forum 2000, nr 3, s. 5, F. Gągor, K. Paszkowski, Międzynarodowe operacje pokojowe w doktrynie obronnej RP, Toruń 1999, s. 19, A. Skowroński, Sity pokojowe i operacje utrzymania pokoju Organizacji Narodów Zjednoczonych, AON, Warszawa 1997, s. 19-23.

${ }^{17}$ A. Jóźwiak, Cz. Marcinkowski, Wybrane problemy wspótczesnych operacji pokojowych, AON, Warszawa 2002, s.13, Międzynarodowe..., s. 18-20.

${ }^{18}$ P. Hudyma, op. cit., s.13.
} 
generation of peacekeeping operations (passive, single-function, military, consensual). The main tasks of the UN peacekeeping forces were monitoring, observation of the separation zone and control over the compliance with the agreements adopted. These activities were conducted during the Cold War - they prevented direct involvement of the great powers in conflicts. Their real success consisted in preventing the possible spread of conflicts on a global scale. Currently, they are often referred to as traditional peacekeeping ${ }^{19}$. An example of such a mission, including diplomatic activity carried out under Chapter VI of the UN Charter, is a typical military observer mission established in June 1948 to supervise the truce in Palestine (United Nations Truce Supervision Organization $)^{20}$, which is currently the longest-functioning UN mission.

The second generation is identified with multifunctional operations, aiming to end the internal conflict ${ }^{21}$. In addition to the military component, operations also include civilian component. For the first time before the beginning of the nineties of the $20^{\text {th }}$ century UN forces were authorized to take actions whose aim was to restore peace ${ }^{22}$. The main reasons for the introduction of these innovations were significant changes in the nature of conflicts, especially the disappearance of traditional interstate conflicts and the outbreak of numerous new internal conflicts, usually undergoing internationalization, requiring unconventional reaction.

The mandate of this type of operation is to ensure the conditions not only to stop fighting, but also to carry out humanitarian actions, full or partial demobilization of the warring sides or withdrawal of the forces and to hold free elections ${ }^{23}$. Before establishment and strengthening of new authorities they also provide temporary administration and conditions for economic and political reconstruction of the state ${ }^{24}$. First operations of this type included Transitional Assistance Group of the United Nations in Namibia (UNTAG 1989-1990) and the United Nations Transitional Authority in Cambodia (UNTAC 1992-1993).

The concept of the third generation of peacekeeping operations defines the activities involving the use of force to compel the conflicting parties to comply with relevant provisions of the Security Council. This is therefore a departure from the principle of impartiality, which was the basic canon of traditional UN peacekeeping operations. Examples of such activities might be the actions taken by the United Nations in the Balkans in the missions of IFOR (Implementation Forces), SFOR (Stabilization Forces) and KFOR (Kosovo Forces) ${ }^{25}$.

The operations of the first and second generation operate in accordance with the classical principles of consent of the parties, impartiality and failing to use force, except in

\footnotetext{
${ }^{19}$ M. Baran, op. cit., s. 12

${ }^{20}$ Rezolucja RB ONZ nr 50/1948 r., J. Rydzykowski, Stownik ONZ, Wiedza Powszechna, Warszawa 2000. s. 148.

${ }^{21}$ I. Popiuk-Rysińska, Ewolucja operacji pokojowych Narodów Zjednoczonych po zimnej wojnie, Stosunki Międzynarodowe nr 1 (t. 27)/2003, s. 24.

${ }^{22}$ A. Jóźwiak, Cz. Marcinkowski, op. cit., s.13.

${ }^{23} \mathrm{~T}$. Bąk, Misje stabilizacyjne i operacje pokojowe metoda rozwiązywania konfliktów militarnych, Zeszyty Naukowe WSOWL, nr 1 (163) 2012, s. 190.

${ }^{24}$ Peacekeeping restructures to strengthen field operations, „United Nation's Peace Operations. Year in Review" 2007, s.7.

${ }^{25}$ Międzynarodowa solidarność. Operacje pokojowe ONZ, NATO i UE, red. J. Dobrowolska-Polak, „IZ Policy Papers” nr 3 (I)/2009, s. 25-26, A. Jóźwiak, Cz. Marcinkowski, op. cit., s. 20.
} 
self-defense. However, in the third generation of operations, the mandate allows for derogations from the rules ${ }^{26}$.

The mandate of the peacekeeping operation is established by Security Council resolution, separately for each case ${ }^{27}$. The action plan of peacekeeping forces is drawn up by Secretary-General, to whom these forces are subordinate. He is also responsible for carrying out the operation. In contrast, field operations management is provided by the commander of peacekeeping forces or the head of the mission appointed by the UN. The forces involved in the actions are international. The state giving their forces at the disposal of the UN for their use in a particular peacekeeping mission shall sign an appropriate agreement with the organization, specifying the conditions of participation.

According to the criteria developed by the Chairman of the Security Council, contained in document S/125859 dated 28 May 1993, the following rules apply to peacekeeping operations ${ }^{28}$ :

1. a clear political goal and precise mandate, subject to periodic review of the Security Council,

2. the consent of the government of the state in whose territory the operation is to be distributed or interested sides (e.g. in the internal conflict), omitted in exceptional cases of violations of international peace and security,

3. support for the political process or for a peaceful resolution of the dispute,

4. impartiality in the implementation of the mandate of the Security Council,

5. readiness of the Security Council to take appropriate measures against parties that fail to comply with its decisions,

6. the right of the Security Council to give the possibility to the UN forces to take all necessary measures, including coercion, for the implementation of their mandate,

7. inalienable right of these forces to the use of coercive measures for the purpose of self-defense,

8. emphasis on the need to find a political solution, so that the peacekeeping operation would not last endlessly.

\section{ARAB - ISRAELI CONFLICT}

Conflicts between Israel and Arab countries date back to the beginnings of the state of Israel, which was founded after the Second World War. The interference of the USSR and the United States gave it a supra-national character. It became an element of the Cold War.

The first war broke out in May 1948, when Egypt, Saudi Arabia, Jordan, Syria, Lebanon, Iraq and the Palestinian militants began the invasion of the young state of Israel in order to liquidate it. Despite the predominance of Arab troops, Israeli troops not only stopped the aggressors, but went on the offensive, after a short truce. This war ended with the enlargement of the territory of Israel by about 7000 square kilometers ${ }^{29}$

\footnotetext{
${ }^{26}$ I. Popiuk-Rysińska, op. cit., s.25.

${ }^{27}$ T. Bąk, op. cit., s. 191.

${ }^{28}$ For more, see Cz. Marcinkowski, Istota i ewolucja misji pokojowych ONZ, „Przegląd HistorycznoWojskowy”, nr 5 (238)/2011, s. 7-20, Międzynarodowe prawo pokoju i bezpieczeństwa, red. L. Łukaszuk, AON, Warszawa 1999, s. 250.

${ }^{29}$ E. M. Nadolski, Wojna Yom Kippur 1973, AJ - Press, Gdańsk 2008, s. 20.
} 
The second conflict took place in 1956 when, on July 26, the President of Egypt Gamal Nasser announced the nationalization of the Suez Canal. This harmed the interests of Britain and France, which attacked Egypt together with Israel, with military success, occupying the Sinai Peninsula ${ }^{30}$. However, Egypt gained both American and Soviet support in the forum of the United Nations. The UN Security Council decided against the intervention, forcing Britain and France to withdraw their troops from the Suez Canal region. Israel also left the territories occupied after 1956 in exchange for placing UN peacekeepers on a demarcation line with Egypt. United Nations Emergency Force I was established $^{31}$. Brazil, Denmark, Finland, India, Indonesia, Yugoslavia, Canada, Colombia, Norway and Sweden sent their soldiers ${ }^{32}$. The task of the UNEF forces was to supervise the conditions of ceasefire and to prevent the entry of Fedayeens ${ }^{33}$ into Israeli territory through a demilitarized border. Egypt also agreed to open the Straits of Tiran for Israeli ships. As a result, the Israeli-Egyptian border remained peaceful for some time.

Arab states started preparing for the next war, in which more and more visible was the support of the great powers. The Americans were arming Israel, whereas the Soviet Union the Arab states (Egypt and Syria) ${ }^{34}$.

The third war of 1967, was provoked, among other things, by G. Nasser's decision to withdraw UN troops dividing Israeli and Egyptian forces and make ship transport impossible for Israel.

Against the background of growing threat, Jews decided on anticipatory action, which began the so-called „Six-Day War” (from 5 June 1967 to 10 June 1967), which ended with the defeat of the Arab countries (Egypt, Syria, Jordan). Israel's territory was enlarged by the Sinai, the Golan Heights, the Gaza Strip, the West Bank of Jordan with the whole of Jerusalem ${ }^{35}$.

Another war broke out on the day of a religious festival of Yom Kippur ${ }^{36}$ in 1973 and lasted from 6 to 26 October. It began with a surprising invasion of the combined forces of Egypt and Syria trying to regain lost territory of the Sinai Peninsula and the Golan Heights. On October 6, 1973 Egyptian troops crossed the Suez Canal and Syrian troops launched the operation on the Golan Heights in order to regain the territories occupied by Israel $^{37}$. The fourth Arab-Israeli war began. It was called „Yom Kippur War”, also known as the „October War” or „Ramadan war” ${ }^{38}$.

${ }^{30}$ For more, see B. Stępniewska-Holzer, J. Holzer, Egipt. Stulecie przemian. Warszawa, Dialog, 2006, s. 124-125.

${ }^{31}$ UNEF I - established on November 7, 1956 under Resolution No. 1001 adopted by the UN General Assembly. This mission operated until June 1967.

${ }^{32}$ M. Kozaczuk, Misje pokojowe wojska polskiego 1953-1978, Warszawa 1978, s. 170.

${ }^{33}$ Someone who is ready to sacrifice his life. http://encyklopedia.pwn.pl/haslo/fedain;3900170.

${ }^{34}$ P. Hadyma, op. cit., s. 35, W. Kozaczuk, op. cit., s. 170.

${ }^{35}$ S. Segev, A Red Sheet: the Six Day War. 1967, s. 82, 175-191.

${ }^{36}$ Atonement Day - one of the most important Jewish holidays. Its central themes are atonement and repentance.

http://www.chabad.org/holidays/JewishNewYYear/template_cdo/aid/671893/jewish/When-is-YomKippur-in-2013-2014-2015-2016-and-2017.htm

${ }^{37}$ For more, see. J. Budziński, W btękitnym hetmie na Synaju i pod Hermonem, MON, Warszawa 1976, s. 167, 231.

${ }^{38}$ L. Zapałowski, op. cit., s. 194,195. 
The attack surprised the Israeli authorities, however, efficient and quick mobilization contributed to the fact that on October 8 Jewish army counterattacked. On October 11 Israelis started attacking the Golan Heights. Having conquered strongly defended fortifications, mechanized Israeli troops entered the territory of Syria, occupying starting positions on the road to Damascus on October 12. Counteroffensive was stopped on October 13, at a distance of about $50 \mathrm{~km}$ from Damascus ${ }^{39}$.

On the territory of the Sinai Peninsula, where the Egyptians attacked on October 14, there was a great tank battle, which the Egyptians lost, like previous time, retreating to a defensive position. The battle stopped the Egyptian offensive, giving the Israelis the opportunity to move to counter-attack ${ }^{40}$.

As a result of actions taken by the US and the USSR and the $\mathrm{UN}^{41}$ resolution on October 24 of that year, the warring sides agreed on a ceasefire ${ }^{42}$.

Due to repeated violations of the provisions of the UN resolutions $(338,339)$ a representative of Kenya, speaking on behalf of the eight member states of the Security Council (Guinea, India, Indonesia, Kenya, Panama, Peru, Sudan and Yugoslavia), presented a draft of a new resolution which was passed by the Security Council ${ }^{43}$ after some amendments, and as a result, UNEF II (United Nations Emergency Force II) ${ }^{44}$ was set up. In this resolution, the Security Council ,decides to immediately create United Nations Emergency Force, acting on its behalf, consisting of troops from the armed forces of the United Nations member states, with the exception of the permanent members of the Security Council...,"45

The Secretary-General outlining the functions and tasks of the UNEF forces announced that they will:

1. Supervise the implementation of the first operative paragraph of resolution 340 calling sides to immediately and fully comply with the cease-fire and withdraw to the positions held by them on 22 October at 16.50 local time.

2. Prevent the resumption of fighting and cooperate with the International Committee of the Red Cross in its humanitarian activities in the region.

3. Cooperate with military observers of the United Nations Truce Supervision Organization in the performance of their duties ${ }^{46}$.

In the implementation of the decision of the Security Council of 1 November 1973, Secretary-General Kurt Waldheim addressed the government of the People's Republic of Poland with a request for separation from the Polish Armed Forces and sending to the Middle East a compact military contingent. On November 8 Political Bureau of the Communist Party and the Polish government declared that they agree to participate in the United Nations Emergency Force in the Middle East ${ }^{47}$.

\footnotetext{
${ }^{39}$ For more, see. J. Biziewski, K. Kubiak, Yom Kippur, Altair, Warszawa 1995.

40 Ibidem.

${ }^{41}$ Rezolucja ONZ nr 338 z dnia 22 października i 339 z 23 października 1973 r.

${ }^{42}$ P. Hadyma, op. cit., s. 37, Ł. M. Nadolski, op. cit., s. 34.

${ }^{43}$ Rezolucja ONZ nr 340 z dnia 25 października 1973 r.

${ }^{44}$ UNEF II funkcjonowały od października 1973 r. do czerwca 1979 r.

45 Ibidem, pkt 3.

${ }^{46}$ L. Zapałowski, op. cit., s. 200.

${ }^{47}$ D. Kozerawski, Polskie Kontyngenty wojskowe w operacjach pokojowych (1973-1999), „Przegląd Historyczno Wojskowy”, Warszawa, 2005, nr 1 s. 92, P. Hadyma, op. cit., s. 38-40, L. Zapałowski, op. cit., s. 205.
} 
At the creation of forces, the so-called principle of equitable political and geographical representation of the contingents was used, according to which contingents represented different continents and political blocks. Beside Poland, such countries as Austria, Finland, Ghana, Indonesia, Ireland, Canada, Kenya (ultimately did not send troops), Nepal, Panama, Peru, Senegal and Sweden agreed to participate in the operation. The first force commander (FC) of UNEF was Finnish general Ensio Siilasvuo, the chief of staff of the UN force in Cyprus - UNFICYP ${ }^{48}$. Also from Cyprus the first troops dividing warring sides in the conflict were deployed.

Poland and Canada were designated to conduct logistic operations. This situation required sharing of the responsibilities between the two armies and forced the armed forces of the two countries, being in opposite political and military blocks, to cooperate. The talks of the representatives of both sides at the UN headquarters, which were to determine the terms of cooperation, lasted from 6 to 22 November $1973^{49}$. In the course of negotiations, it was established that the Poles will deal with running engineering works (repair of roads, mine clearance, construction and repair of barracks), transport of supplies, extraction and treatment of drinking water and the organization of the hospital for the whole contingent. The Canadians were to deal with maintenance, communication signals and air transport including the control of the movement of people and goods. Both contingents also agreed to give their representations to the military police ${ }^{50}$.

The first change in the Polish contingent was organized on the basis of the 6th Pomeranian Airborne Division (6th PAD) from Krakow, which was organizationally subordinated to the commander of the Warsaw Military District. Taking into account the tasks which the contingent was to implement in the mission area, it was strengthened with specialists from other units of the Warsaw Military District. The transport company was formed from the 10th Sudecka Armoured Division from Opole. The commander of the first shift was colonel Jerzy Jarosz ${ }^{51}$, a chief of staff of 6th PAD.

The operation was completed in 197952. In total, 11699 people (including 4037 professional soldiers, 7080 conscript soldiers and 582 civilian employees) did military service in this operation.

\section{UNITED NATIONS DISENGAGEMENT OBSERVER FORCE (UNDOF)}

Another UN peacekeeping operation, participated in by the Poles, was the mission in Syria, in the area of the Golan Heights. The operation, in same way as the mission of UNEF II, was the final point of the ending of Syria-Israel conflict (1973.). As a result of the agreement on May 1974 in Geneva, United Nations Disengagement Observer Force

\footnotetext{
${ }^{48}$ UNFICYP (United Nations Peacekeeping Force in Cyprus) - peacekeeping mission in Cyprus, established by virtue of Resolution 186 of UN Security Council of 4 March 1964. L. Zapałowski, op. cit., s. 159-188.

${ }^{49}$ T. Mulicki, Operacje pokojowe ONZ na Bliskim Wschodzie, „Sprawy Międzynarodowe”, 1975, nr 4, s. 42.

${ }^{50}$ D. Kozerawski, op. cit., s. 92.

${ }^{51}$ Jerzy Jarosz (born on August 18, 1931 in Nagawczyn, near Dębica) - in October 1978 Brigadier General of the Polish Army. Retired on 20 February 1992. J. Królikowski, Generałowie $i$ admiratowie Wojska Polskiego 1943-1990 t. IV: S-Z, Toruń 2010, s. 68-71.

${ }^{52}$ L. Zapałowski, op. cit., s. 215-16.
} 
(UNDOF) ${ }^{53}$ was created. This name is a compromise between the demands of Syria to appoint only UN military observer mission with an extended operation mandate, and the pressure of Israel to create a United Nations peacekeeping force. The negotiated agreement largely resembled the Egyptian-Israeli agreement. The difference lied in the fact that the power in the created buffer zone, with a width of 2-6 kilometers and a length of about 70 kilometers, from the top of Herman mountain to the border with Jordan, was not in the hands of the United Nations Emergency Force but was taken over by Syrian administration $^{54}$.

During the formation of the mission they adopted the theory of forming fourcontingent representation of forces by two neutral countries, one belonging to NATO and one from the Warsaw Pact: Austria, Peru, Canada and Poland. In this arrangement, the two contingents (states) formed the core of operations (Austria - AUSBATT and Peru PERBATT) and the core of logistics (Canada - CANLOG and Poland - POLLOG) ${ }^{55}$. UNDOF was an independent formation of the United Nations, but in terms of logistics closely cooperated with UNEF II. UNDOF received a mandate for six months, renewed for further periods, up to the present day.

In 1978, the Peruvian contingent was replaced with the Iranian one, which in turn, in 1979, was replaced by the Finnish contingent.

The tasks of this mission consisted mainly in constant control of the situation from the observation posts located in the zone of separation, reporting of any breach of the zone area, as well as ensuring compliance with the prohibition on the gathering of weapons there ${ }^{56}$.

First Polish UNDOF soldiers came from the second shift of UNEF II. On 4 June 1974 they began deployment from Egypt to the Golan Heights. The column of 39 vehicles stretched for a length of about two kilometers. This group set off from the Suez Canal, went through Sinai, the Gaza strip, the territory of Israel and finished the march in the area of the Syrian Golan Heights. The distance of 750 kilometers was covered within 36 hours. On the whole route the column was escorted by Israeli military police. Poland did not maintain diplomatic relations with Israel then. In the first period, the POLLOG had about 92 soldiers, subordinated to the Polish Special Military Unit (PSMU) in Egypt, and was called Separate Group of PSMU (SGPSMU).

The tasks of the SGPSMU included:

1. adaptation of the camp,

2. mine clearance of roads and the area and their systematic control,

3. renovation of buildings and infrastructure necessary for the functioning of the UN bases,

4. the transport of people, building materials, equipment and food to the camp and Austrian posts ${ }^{57}$.

These actions took place in a difficult situation. The military base was not prepared,

\footnotetext{
${ }^{53}$ Rezolucji S/RES/350 Rady Bezpieczeństwa z 31 maja 1974 r.

${ }^{54}$ L. Zapałowski, op. cit., s. 210.

${ }^{55}$ The Blue Helmets, A Review of United Nations Peace-keeping, New York 1996, s. 75.

56 G. Ciechanowski, Misje pokojowe ONZ na bliskim wschodzie $w$ okresie zimnej wojny, Bezpieczeństwo Teoria i Praktyka 2 (XI) 2013, s. 98.

${ }^{57}$ A. Baranowski, Bliski Wschód doświadczenia i wnioski cz. II Syria, „Przegląd Wojsk Lądowych”, 1976, Warszawa, nr 1, s. 91.
} 
heavy mountain conditions made it difficult to work for POLLOG, equipped with not adapted Polish Star 660 terrain trucks and Nysa vans. However, according to different opinions, SGPSMU performed its tasks very well ${ }^{58}$.

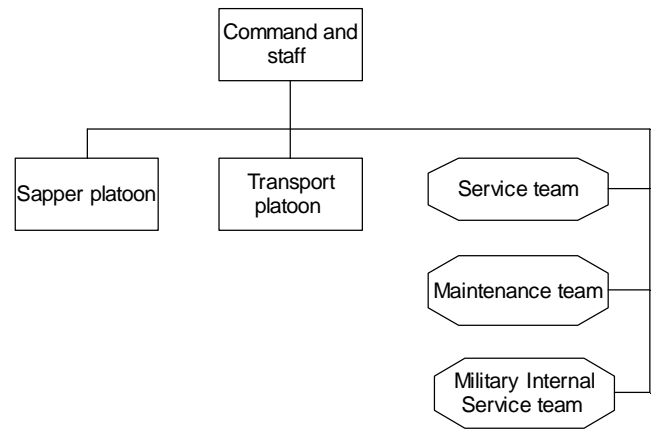

Fig. 1. Organizational structure of POLLOG (SGPSMU) in the years 1974-1979

Source: own study based on http: //peacekeeping/missions/undof/resources.shtml

Major changes occurred in 1979, when the UNEF II mandate ended and PSMU was withdrawn to the country. This meant the independence of the SGPSMU, which was strengthened with 60 soldiers and transformed into the Polish Military Contingent (PMC) in Syria.

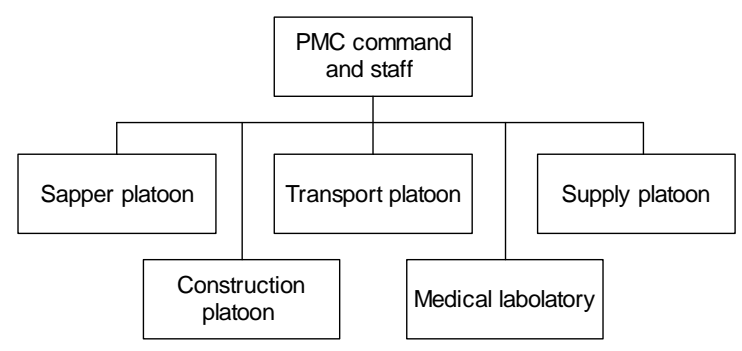

Fig. 2. Organizational structure of PMC (POLLOG) in the years 1979-1993

Source: own study based on http: //peacekeeping/missions/undof/resources.shtml

Its tasks remained unchanged. In 1992 there were modifications in the structure of UNDOF, which resulted in the reduction of POLLOG to approx. 130 people, whereas FINBATT began to withdraw (the Finnish government argued that this was caused by economic problems) and it was decided that its place will be taken by POLBATT.

\footnotetext{
${ }^{58}$ Ibidem, s. 93, S. Konieczny, Bliski Wschód doświadczenia i wnioski. Przygotowania do pokojowej misji, „Przegląd Wojsk Lądowych”, Warszawa, 1980, nr 12, s. 85.
} 
Polish logistic unit performed its tasks until December 1993 when its duties were taken over by the Canadian contingent ${ }^{59}$. Until then there were 38 shifts of POLLOG on the Golan Heights, amounting to 3662 soldiers and civilian employees in total. Dissolution of POLLOG was associated with restructuring of extended UNDOF forces. Implementation of this project was entrusted to Major-General Roman Misztal ${ }^{60}$

Table 1. The number of Polish soldiers in UNDOF

\begin{tabular}{|c|c|c|}
\hline Name of the unit & Years & $\begin{array}{c}\text { Headcount } \\
\text { (approx.) }\end{array}$ \\
\hline \multirow{2}{*}{ POLLOG } & $1974-1979$ & 90 \\
\cline { 2 - 3 } & $1979-1992$ & 150 \\
\cline { 2 - 3 } & $1992-1993$ & 130 \\
\hline POLBATT & $1993-2009$ & 360 \\
\hline
\end{tabular}

Source: own study based on http://skmponz.pl/misje-pokojowe-polakow-1953-2010/

A logistic unit was replaced by an operational battalion (PMC POLBATT), which officially took over the task of Finnish troops on December 8, 1993. It was entrusted with supervising the separation zone of the southern sector, in the shape of a wedge with a length of over 50 kilometers and a width of approx. 9 kilometers, located between Israeli and Syrian positions.

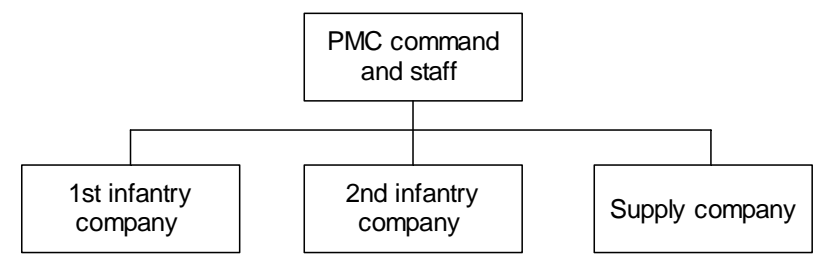

Fig. 3. Organizational structure of PMC (POLBATT) between 1993-2009

Source:http://www.un.org/en/peacekeeping/missions/undof/documents/40_anniversary_coffe e_table_book_WS.pdf $(01.10 .2014)$

Since that time, the most important tasks of the of PMC included:

1. supervising the area of responsibility and organizing patrols, as recommended by UNDOF Headquarters,

2. deployment of rapid reaction groups in a controlled area (according to the orders)

\footnotetext{
59 J. Sroka, Polskie jednostki logistyczne w sitach utrzymania pokoju na Bliskim Wschodzie w latach 1973-1992, „Myśl Wojskowa”, Warszawa, 2005, nr 4, s. 168.

${ }^{60}$ Roman Misztal (born on May 11, 1932 in Poczapy - a village in Ukraine) - Retired Major General of Armed Forces of the Republic of Poland (SZ RP), military intelligence soldier of Armed Forces of the People's Republic of Poland (SZ PRL) and Armed Forces of the Republic of Poland. From September 1991 to November 1994 UNDOF commander. The first Pole who took the prestigious position of a commander of the armed forces of the UN peacekeeping mission. J. Królikowski, Generałowie i admirałowie Wojska Polskiego 1943-1990 t. II:I-M, Torun 2010, s. 520-522.
} 
in order to ensure compliance with the provisions of the agreement between Israel and Syria,

3. construction of fortifications around objects, and in addition,

4. providing assistance to local people, where possible, organizing meetings with the Polish community living in Israel and Syria.

Command, staff, logistics and supply company were deployed at Camp Ziouani (on the Israeli side), and the 1 st and 2nd company (each consisting of two platoons) in the zone of PMC responsibility on the Syrian side ${ }^{61}$.

In the years 1993-2009 in the mission in the Golan Heights participated nearly 10 thousand Polish soldiers and military workers. In February 2009 Defense Minister Bogdan Klich announced the withdrawal of Polish troops from the Golan Heights ${ }^{62}$.

After 35 years of presence and performance of the tasks of the mandate, the $31^{\text {st }}$ shift of PMC UNDOF was the last shift. On October 22, 2009 there was a solemn transfer of responsibilities between Polish and Philippine military contingent in the Golan Heights.

At the moment of its dissolution, PMC UNDOF was the oldest, lasting almost 36 years, military service of Polish soldiers under the blue UN flag ${ }^{63}$.

\section{CONCLUSION}

Almost 42 years ago, the first Polish military unit took part in peacekeeping operation within the UN framework. In the years 1974-2009 approximately 13 thousand Polish soldiers and military workers participated in the mission on the Golan Heights.

Missions were the source of analysis carried out by staff officers, aimed at better preparation for further shifts and more efficient and above all safer work under the UN peacekeeping force. Polish Armed Forces participation in foreign missions has contributed to the restructuring of the army in technology, quality and mentality.

Unfortunately, Poland does not currently participate in UN peacekeeping missions, since it engaged in NATO missions. The main reason for this decision was the difficult financial situation of Defense Ministry.

Many years of active participation in UNDOF forces have helped to shape the image of Poland as a participant in peacekeeping missions under the auspices of the United Nations.

\section{REFERENCES}

[1] Baran M., Zabezpieczenie logistyczne Polskiego Kontyngentu Wojskowego w misji pokojowej (na przykładzie KFOR), praca studyjna - maszynopis [mps], AON, Warszawa 2003.

[2] Baranowski A., Bliski Wschód doświadczenia i wnioski cz. II Syria, „Przegląd Wojsk Lądowych”, 1976, Warszawa, nr 1.

[3] Bąk T., Misje stabilizacyjne $i$ operacje pokojowe metoda rozwiazywania konfliktów militarnych, Zeszyty Naukowe WSOWL, nr 1 (163) 2012.

[4] Bezpieczeństwo Świat-Europa Polska, red. J. Kaczmarek, Alta, Wrocław, 1998.

61 J. Kamola, Polski Kontyngent Wojskowy na Wzgórzach Golan, „Przegląd Wojsk Lądowych”, Warszawa, 2003, nr 11, s. 29-30, P. Hudyma, op. cit., s. 63.

${ }^{62}$ E. Żemła, E. Olczyk, Rzą rezygnuje z misji wojskowych, Rzeczpospolita 04-02-2009 r.

${ }^{63}$ http://skmponz.szczecin.pl/pkw-undof/ 
[5] Biziewski J., Kubiak K., Yom Kippur, Altair, Warszawa 1995.

[6] Budziński J., W błękitnym hetmie na Synaju i pod Hermonem, MON, Warszawa 1976.

[7] Ciechanowski G., Misje pokojowe ONZ na bliskim wschodzie w okresie zimnej wojny, Bezpieczeństwo Teoria i Praktyka 2 (XI) 2013.

[8] Ciechański J., Wyciechowska I., Teoria pokoju a Organizacja Narodów Zjednoczonych, Sprawy Międzynarodowe, Akademia Dyplomatyczna, nr 6, Warszawa 1990.

[9] Czapliński W., Wyrozumska A., Prawo międzynarodowe publiczne. Zagadnienia systemowe, wyd. II, C.H. Beck, Warszawa 2004.

[10]Gągor F., Paszkowski K., Międzynarodowe operacje pokojowe $w$ doktrynie obronnej RP, Toruń 1999.

[11]Hudyma P., Udziat wojsk polskich $w$ misjach zagranicznych o charakterze pokojowym $i$ stabilizacyjnym, w latach 1953-2008, praca doktorska - mps, Poznań 2011.

[12]Jóźwiak A., Marcinkowski Cz., Wybrane problemy wspótczesnych operacji pokojowych, AON, Warszawa 2002.

[13] Kamola J., Polski Kontyngent Wojskowy na Wzgórzach Golan, „Przegląd Wojsk Lądowych", Warszawa, 2003, nr 11.

[14]Kinloch-Pichat S., International Peacekeeping, Disarmament and International Force: A Circular Proposition, (Peacekeeping: evolution or extinction?). Disarmament Forum 2000, nr 3.

[15] Konieczny S., Bliski Wschód doświadczenia i wnioski. Przygotowania do pokojowej misji, ,Przegląd Wojsk Lądowych”, Warszawa, 1980, nr 12.

[16] Kozaczuk M., Misje pokojowe wojska polskiego 1953-1978, Warszawa 1978.

[17] Kozerawski D., Polskie Kontyngenty wojskowe w operacjach pokojowych (19731999), „Przegląd Historyczno Wojskowy”, Warszawa, 2005.

[18]Królikowski J., Generałowie i admirałowie Wojska Polskiego 1943-1990 t. t. II I-M, IV: S-Z, Toruń 2010.

[19]Limanowski J.T., Operacje pokojowe Organizacji Narodów Zjednoczonych, AON, Warszawa 2011.

[20]Łoś-Nowak T., Organizacje w stosunkach międzynarodowych, Wrocław 1997.

[21]Łukaszuk L.,Skowroński A., Międzynarodowe prawo pokoju i bezpieczeństwa, AON, Warszawa 1999.

[22]Marcinkowski Cz., Istota $i$ ewolucja misji pokojowych ONZ, „Przegląd Historyczno-Wojskowy", nr 5 (238)/2011.

[23]Malendowski W., Rola ONZ w utrzymaniu pokoju $i$ bezpieczeństwa międzynarodowego, [w:] Stosunki międzynarodowe, red. W. Malendowski, Cz. Mojsiewicz, Atla 2, Wrocław 2004.

[24]Międzynarodowa solidarność. Operacje pokojowe ONZ, NATO i UE, red. J. Dobrowolska-Polak, „IZ Policy Papers” nr 3 (I)/2009.

[25] Międzynarodowe operacje pokojowe $w$ doktrynie obronnej RP, red. F. Gągor, Adam Marszalek, Warszawa 1998.

[26] Międzynarodowe prawo pokoju i bezpieczeństwa, red. L. Łukaszuk, AON, Warszawa 1999.

[27]Mulicki T., Operacje pokojowe ONZ na Bliskim Wschodzie, „Sprawy Międzynarodowe", 1975, nr 4. 
[28]Nadolski Ł.M., Wojna Yom Kippur 1973, AJ - Press, Gdańsk 2008.

[29]Popiuk-Rysińska I., Ewolucja operacji pokojowych Narodów Zjednoczonych po zimnej wojnie, Stosunki Międzynarodowe nr 1 (t. 27)/2003.

[30] Rezolucja RB ONZ nr 50/1948 r.

[31]Rezolucja ONZ nr 338 z dnia 22 października i 339 z 23 października 1973 r.

[32] Rezolucja ONZ nr 340 z dnia 25 października 1973 r.

[33]Rezolucji S/RES/350 Rady Bezpieczeństwa z 31 maja 1974 r.

[34] Rydzykowski J., Stownik ONZ, Wiedza Powszechna, Warszawa 2000.

[35] Segev S., A Red Sheet: the Six Day War. 1967.

[36]Skowroński A, Sity pokojowe i operacje utrzymania pokoju Organizacji Narodów Zjednoczonych, AON, Warszawa 1997.

[37] Stępniewska-Holzer B., Holzer J,, Egipt. Stulecie przemian. Warszawa, Dialog, 2006.

[38] Sroka J., Polskie jednostki logistyczne w siłach utrzymania pokoju na Bliskim Wschodzie w latach 1973-1992, „Myśl Wojskowa”, Warszawa, 2005, nr 4.

[39]The Blue Helmets, A Review of United Nations Peace-keeping, New York 1996.

[40]Zapałowski L., Operacje pokojowe ONZ, KAW, Kraków 1989.

[41]Żemła E., Olczyk E., Rzad rezygnuje z misji wojskowych, Rzeczpospolita 04-022009 r.

[42] http://www.refworld.org/pdfid/492e81ba2.pdf.

[43] http://www.un.org/en/peacekeeping/missions/undof/documents/40_anniversary _coffee_table_book_WS.pdf.

[44] http://skmponz.szczecin.pl/pkw-undof/.

[45]http://skmponz.pl/misje-pokojowe-polakow-1953-2010/

[46] http://www.chabad.org/holidays/JewishNewYear/template_cdo/aid/671893/jewis $\mathrm{h} /$ When-is-Yom-Kippur-in-2013-2014-2015-2016-and-2017.htm.

[47] http://www.un.org/en/sc/members/.

[48]http://encyklopedia.pwn.pl/haslo/fedain;3900170.html

\section{UDZIAŁ WOJSKA POLSKIEGO W MISJI ONZ NA WZGÓRZACH GOLAN -} UNITED NATIONS DISENGAGEMENT OBSERVER FORCE

W artykule przedstawiono problematykę udziału Wojska Polskiego w misji zagranicznej UNDOF (United Nations Disengagement Observer Force), historię jego udziału oraz zmiany w charakterze misji. W pierwszej części artykułu przedstawiono podstawy prawne prowadzenia misji pokojowych pod auspicjami ONZ, koncepcję użycia sił pokojowych ONZ jako jednego ze środków służących pokojowemu rozwiązywaniu konfliktów. Omówiono typy operacji prowadzonych przez Organizację Narodów Zjednoczonych, a mianowicie: Operacje Pierwszej Generacji, Operacje Drugiej Generacji i Operacje Wymuszania Pokoju. Operacje pierwszej i drugiej generacji funkcjonują zgodnie z zasadami zgody stron, bezstronności, nieużycia siły $\mathrm{z}$ wyjątkiem samoobrony. W Operacjach Wymuszenia Pokoju mandat dopuszcza możliwość odstępstwa od tych zasad. W opracowaniu omówiono ważniejsze konflikty izraelsko-arabskie, które stały sie przyczynkiem do interwencji ONZ na Bliskim Wschodzie. Następnie opisano pierwszą operację pokojowa na półwyspie Synaj, w której Wojsko Polskie wzięło udział jako jednolity narodowy kontyngent (1973-1979), któremu powierzono określone zadania w ramach sił Narodów Zjednoczonych. Misja otrzymała nazwę UNEF II (United Nations Emergency Force II). Kontyngent ten odpowiedzialny był za zabezpieczenie logistyczne: medyczne, dostawa wody pitnej i żywności, oraz rozminowywanie terenu. Drugą operacją pokojową, w której wzięli udział Polacy, była misja na Wzgórzach Golan - UNDOF. 
Operacja ta, podobnie jak misja w Egipcie (UNEF II), była wynikiem wojny arabskoizraelskiej w 1973 r.. Obecność sił pokojowych stała się możliwa po porozumieniach zawartych w maju 1974 r. w Genewie, pomiędzy Syrią a Izraelem. Zadaniem sił pokojowych było nadzorowanie rozejmu między zwaśnionymi stronami. Misja ta była najdłużej trwającą misją Wojska Polskiego (1974-2009).

Słowa kluczowe: misje pokojowe ONZ, misja UNDOF, Wojsko Polskie w misjach pokojowych.

DOI:10.7862/rz.2015.hss.10

Przesłano do redakcji: listopad 2014

Przyjęto do druku: maj 2015 